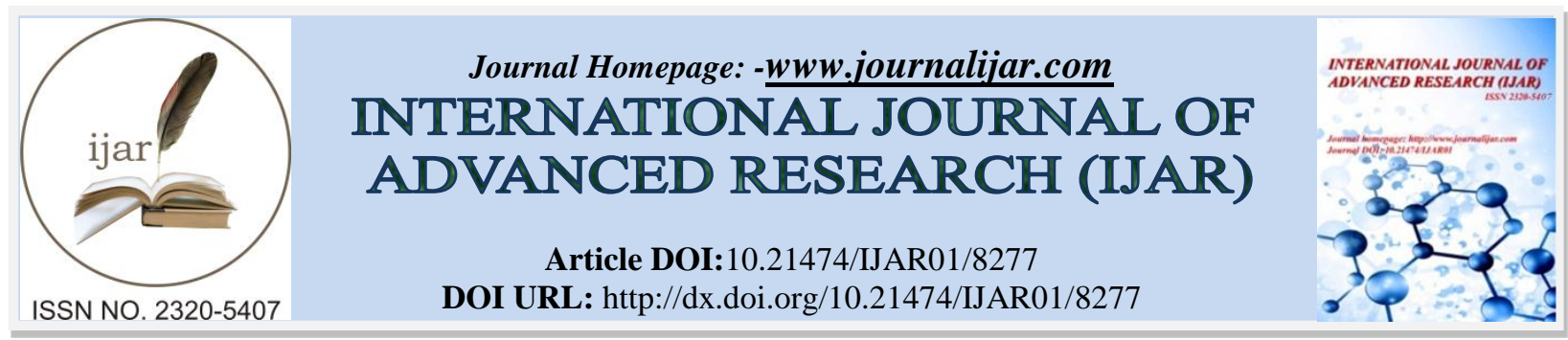

RESEARCH ARTICLE

\title{
SIMULATION MODEL OF RISK TREATMENT FOR CANESUGAR PRODUCTION PROCESS WITH A SYSTEM DYNAMIC APPROACH.
}

\section{Suripto $^{1}$, Machfud ${ }^{2}$, M. Romli ${ }^{2}$ and AHY Rosidi ${ }^{3}$.}

1. Center of Technology Specific Region and inovation system, Agency for The Assessment and Application of Technology (BPPT), Gd. 720 Kawasan Puspiptek Serpong, Tangerang Selatan, Indonesia - 15314.

2. Department of Agroindustrial Technology, Bogor Agricultural University, Bogor, West Java, Indonesia 16002.

3. Center of Technology Audit System- Agency for The Assessment and Application of Technology (BPPT), Gd. 720 Kawasan Puspiptek Serpong, Tangerang Selatan, Indonesia - 15314.

\section{Manuscript Info}

\section{Manuscript History}

Received: 20 October 2018

Final Accepted: 22 November 2018

Published: December 2018

Key words:-

sugar agroindustry, system dynamics, risk, risk management.

\begin{abstract}
The risks within the continuous production process of perishable agricultural products are inherently complex and dynamic. Risks of raw material supply activities affect the activity itself and its subsequent activities. Analysis results of interpretive structural modeling (ISM) on risk measurement of sugar cane production processes indicate that risk management in sugarcane raw material supply will support other risk handling measures. The simulation results with a system dynamics approach show that risk treatment in the sugarcane supply activities, namely overcoming lack of harvesting labor by increasing semimechanical harvesting (SM) and level of sugarcane cleanliness by tightening the implementation of standard operational procedure (SOP), has positive changes in sugarcane supply performance, the performance of milling, processing and generator processes such as daily milling average, SHS sugar production, yield, amount of crystal, and electricity production.
\end{abstract}

Copy Right, IJAR, 2017,. All rights reserved.

\section{Introduction:-}

Indonesia's sugar industry generally suffers low productivity and efficiency level, especially in the state-owned sugar industry (Subiyanto, 2017). Data from the Indonesian Sugar Association (AGI) report on 2017 shows that the yield performance of Indonesia's sugar industry is 7.37\% (AGI, 2018). Such figure is far from the similar industries in world sugar-producing countries such as Thailand (12.27\%). This shows that the competitiveness of Indonesian sugar cane industry is low. Various studies proposed ways to increase crystal sugar production by improving sugar factories performance, including through machinery revitalization and establishment of new sugar mills.

In the perspective of risk management, productivity and efficiency problems occur due to the mishandling of risks. With risk management, opportunities and risk impacts can be managed to improve company's performance and competitive advantage. Bromiley, McShane, Nair, and Rustambekov (2015) confirmed that risk management is a potential source for a competitive advantage.

Corresponding Author:- Suripto.

Address:- Center of Technology Specific Region and inovation system, Agency For The Assessment and Application of Technology (BPPT), Gd. 720 Kawasan Puspiptek Serpong, Tangerang Selatan, Indonesia -15314 
Many researchers, such as Sriwana (2006) and Rohmatulloh, Marimin, Machfud, and Nasution (2009) proposed a systemic approach to overcome problems and to improve off-farm performance in sugar mills. The systemic approach of taking into account the dynamic elements of the system has been suggested by Rohmatulloh, Marimin, Machfud, and Nasution (2011) for sugar mill; Dibyoseputro (2012) and Haryono, Hendriadi, Sembiring, Unadi, and Nurjaman (2012) for sugar industry, while Patill, G.S.Yarnal., and V.S.Puranik (2008) use the approach to discuss energy management in sugar mills.

Within a complex system, the interrelationship occurs among its components. Interference in one component will affect other system component while the risk changes over time as a dynamic risk. Therefore, risk treatment will also be interrelated; one measure will relate to another. An interaction between risks will produce a greater impact. The linkages between risks have an indirect impact. Minami, Madnick, and Rhodes (2008) suggest the use of dynamic system as a methodology and tools to model complex problems that require risk management solutions. Nasirzadeh, Afshar, Khanzadi, and Howick (2008) suggest using the use of dynamic systems due to the dynamic nature of risk, the ability to mesure indirect impact of risk, the ability to simultaneously measure the impact of several performance indicators, and its quantitative measurements.

The use of dynamic systems in supply chain risk management to reduce the bullwhip effect has been studied by Sidola, Kumar, and Kumar (2011) in management, and by Campuzano and Mula (2011) for broader risks. Wan and Liu (2014) analyzed project risk, while Nikolaou, Evangelinos, and Leal Filho (2014) employ the approach to study the impact of climate change risks on the company's operating performance.

This study aims to design a simulation model of risk treatment with a system dynamics approach.

\section{Research Methodology:-}

\section{Data collection method:-}

Data collection is performed through:

1. Literature study on research related to sugar cane production processes, risk management, dynamic simulation concepts

2. Collecting information and secondary data related to process and production data

3. Semi-structured and in-depth interviews to explore sugar mills system.

\section{Selection of risk management measures:-}

Suripto, Machfud, Romli, and Rosidi (2018) identified and assessed the risk of the sugarcane production process in PG. X and found the priority scale of management. There are 9 risks treatment that has been ranked according to the effectiveness to difficulty ratio (Table 1). These finding were analyzed using the interpretive structural modeling (ISM) technique to obtain an interrelationship among risk treatment. The procedures and stages of ISM analysis can be seen in Marimin (2004).

Table 1:-Ranking of risk treatment based on the total effectiveness to difficulty ratio

\begin{tabular}{|l|l|}
\hline 1. & M.01: Improvement of harvest and supply (TMA) management planning with rainfall days forecast \\
\hline 2. & M.05: Improvement of TMA in supply management \\
\hline 3. & M.04: Improvement of communication systems among production line with TMA \\
\hline 4. & M.06: Control of bagasse quality through mill and sugar cane cleanliness \\
\hline 5. & M.03: Tightly of SOP TMA, Reward \& Punishment \\
\hline 6. & M.09: Tightly controlling sugarcane from soil and sand before milling \\
\hline 7. & M.08: The use of lime and lime milk production process according to the standards \\
\hline 8. & M.07: Regular maintenance and repair of mill roll coat \\
\hline 9. & M.02: Conduct controlled stop-milling together with engine repair schedules \\
\hline
\end{tabular}

Source:- Suripto et al. (2018)

\section{Modeling Stages:-}

Sterman (2000) argues that there is no standard procedure in modeling to guarantee the usefulness of a model. Each procedure has their way. In this study, the following stages are used: 


\section{Model Identification:-}

As an initial step to understanding the real system, the problem definition, goal setting, scope (model boundary) and simulation time were carried out. At this stage, key very influential variables are identified to construct system model.

\section{Model Design:-}

1. Construction of a Causal loop diagram. Causal loop is an illustration of a mental model or conceptual model as an implementation of system structure understanding. Causal loop diagram describes the causal relationship between system elements, including the key variables. The relationship between variables in a causal diagram can be positive and negative. The positive causal relationship is defined for the situation where the change between two variables is in the same direction and vice versa. Negative causal relationship occurs if the changes in the two related variables are not in the same direction. Likewise, with the form of feedback loop, there is a positive feedback loop (growth behavior) and a negative feedback loop (behavior of goals achievement).

2. Computation. Models that have been constructed in the conceptual model are then formulated into simulation models in the form of stock flow diagrams, mathematical equations, and computer programs. At this stage, the level variable (stock) and the rate variable (flow) is observed.

\section{Model Testing:-}

Model testing is performed by verifying and validating the model. Verification is an attempt to ensure that the designed model is able to carry out simulations of the studied abstract model (Eriyatno, 2012), or to ensure that the compilation of computer simulation models on the conceptual model has been done correctly (Sargent, 2012). Verification is performed by checking whether all assumptions input and output parameters have been included in the model and whether the model has been designed with a logical structure. Validation is an attempt to ensure that the model designed can represent the real system (Eriyatno, 2012).

\section{Data Sources:-}

The data source to analyze and design simulation models of risk management with a system dynamics approach is the volume of sugarcane entering the emplacement and the daily milled volume. The data is coming from daily milling reports of PG X in 2015. The production process of PG.X is illustrated in Figure 1 while the sugarcane pattern that enters to emplacement can be seen in Figure 2.

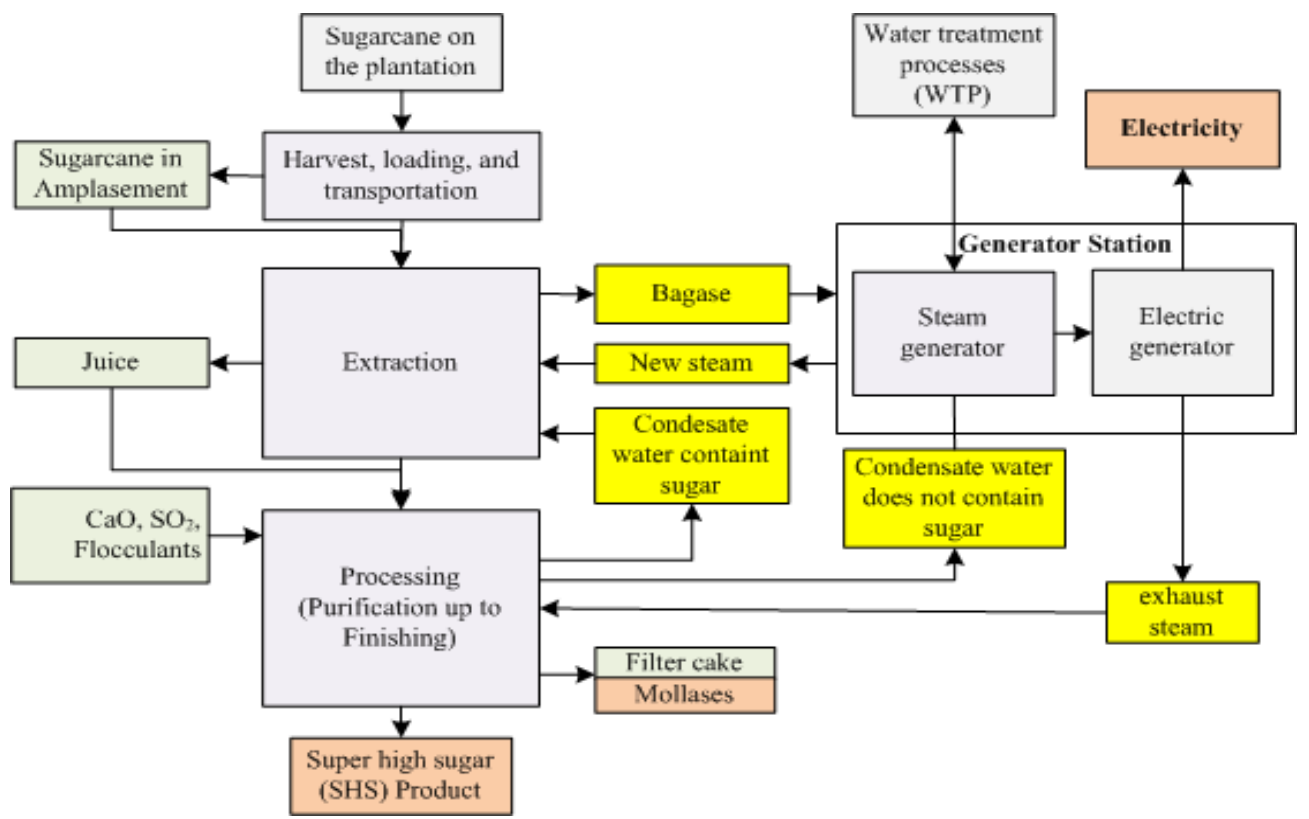

Figure 1:-Sugarcane production process of PG. X 


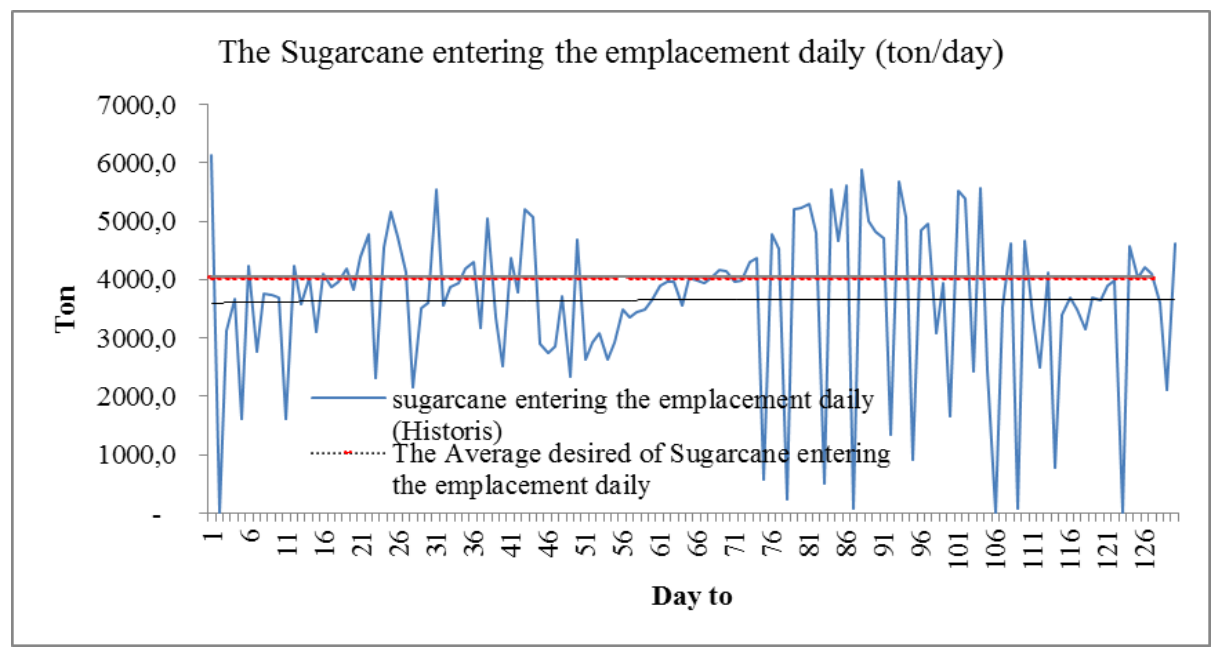

Figure 2:-Graph of the amount of sugarcane which enter to emplascementon historical daily record basis in 2015

Figure 1:-Shows daily fluctuations of sugar cane supply with an average of 3,494 tons/day or $86 \%$ of 4,050 tons/day factory mill capacity. These fluctuations are a risk due to supply instability caused by lack of harvest labor, rainfall, and/or transportation equipment failure. In 2015, the average level of sugarcane contamination (trash) reached $11.6 \%$ while sugar cane cleanliness standard was bellow $5 \%$.

\section{Results and Discussion:-}

\section{Structure and characteristics of risk treatment:-}

According to the results of ISM analysis, the characteristics of risk treatment were obtained according to Driver Power and Dependence level (Figure 3) and the hierarchical structure of the relationship between risk treatments (Figure 4). The results of the ISM analysis also showed that the key elements of risk treatment were:

1. Improvement of TMA planning management with rainy days forecast

2. Improvement of TMA management in supply management

3. Improvement of communication systems among production line with TMA

4. Thighty of SOP TMA, Reward \& Punishment

This shows that these elements has very important role in encouraging other risks treatment and their success.

\section{Model Design:-}

Risk management model of the sugarcane production process is a system dynamic model built based on the sugar production process system, from post-harvest to the completion of the final product namely white crystal sugar, as well as generator a utility system in the production process. The designed model is intended to determine the impact of risk treatment on sugar factory performance. The risk analyzed is the risk that affects during the milling season, so the simulation time span is the milling season.

In this study, risk treatments are obtained through a gradual process starting from identifying, analyzing and determining risk priorities. The prioritized risks are then formulated for management measures. The risk treatments that will be applied are those which have high effectiveness, low levels of difficulty in implementation and high impetus towards other risk treatment. Before implemented, such measures will be simulated in a risk management simulation model with a system dynamics approach. 


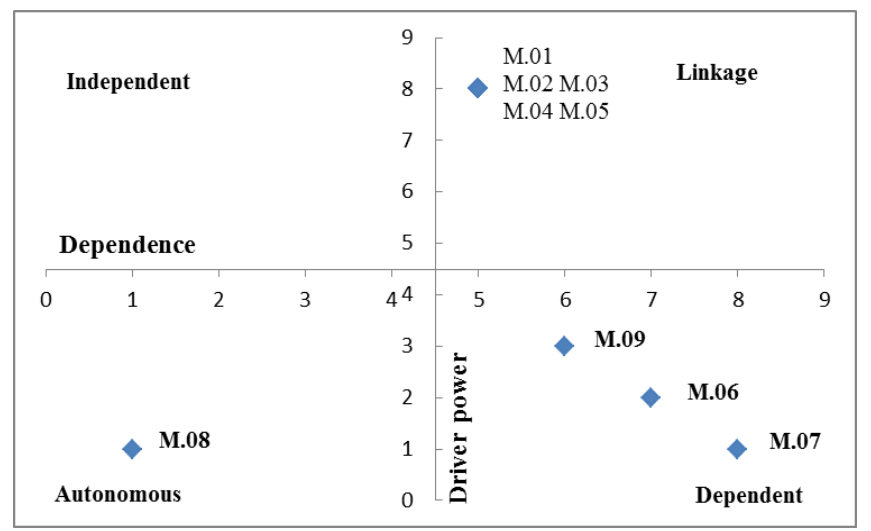

Figure 3:- Grouping of risk treatment characteristics based on power driver and dependency levels

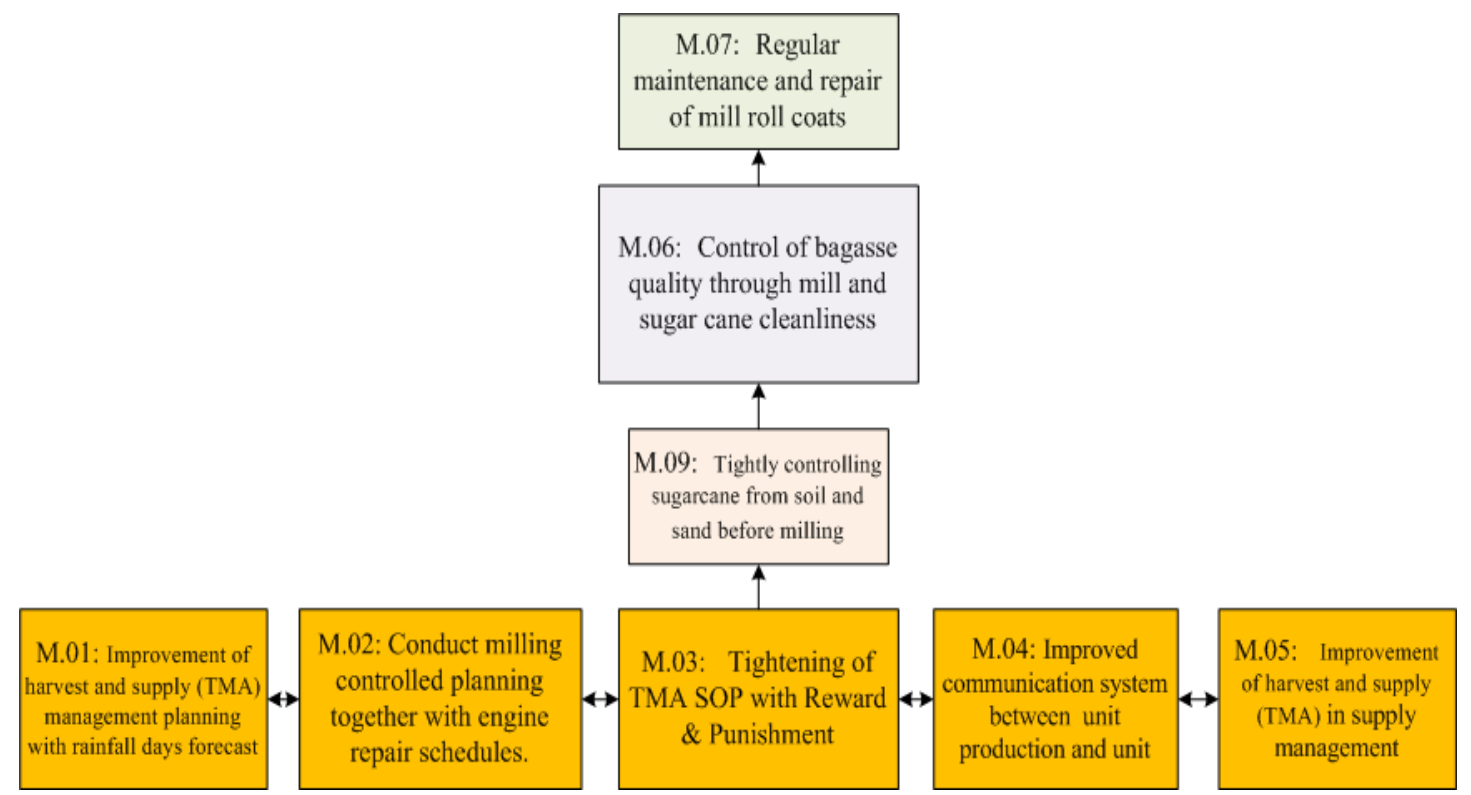

Figure 4:-Hierarchy Structure between the elements of risk treatment on sugar cane production process

Output of risk treatment from the simulation on the System Dynamic model is limited to (i) sugarcane supply and quality as TMA sub-system performance, (ii) bagasse and water content as mill sub-system performance, (iii) steam and electricity production as cogeneration sub-system performance, and (iv) sugar yield and production as manufacturing sub-system performance.

\section{System Dynamic Model:-}

The conceptual model of risk management with a dynamic system approach is described in a causal loop and stock flow diagrams. The causal loop diagram is shown in Figure 5. 


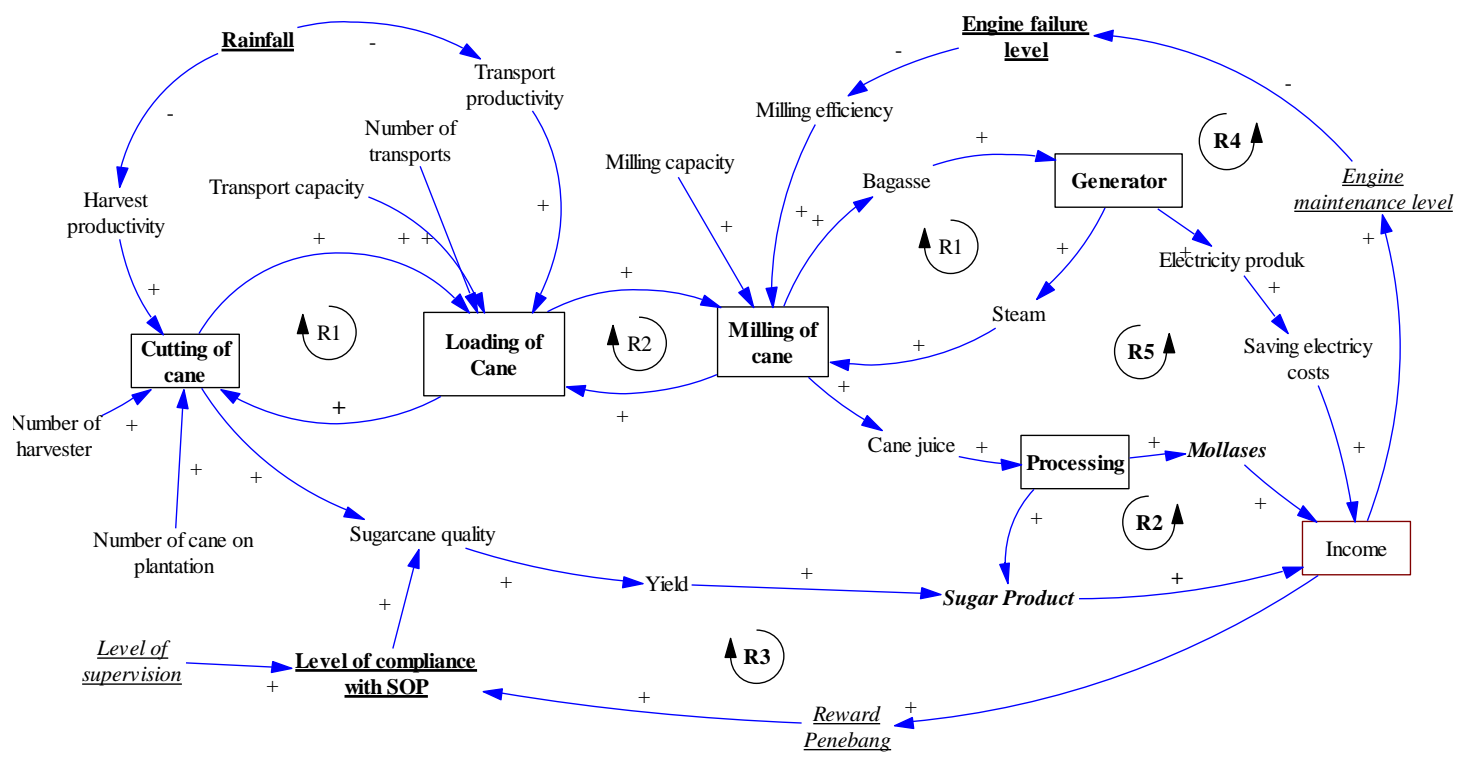

Figure 5:- Causal loop diagram in sugarcane production process

Such conceptual or causal loop diagram model basically consists of 5 main sub-models: transporting, milling, manufacturing, generator, and income. The five sub-models are depicted in the model structure as shown in Figure 6.

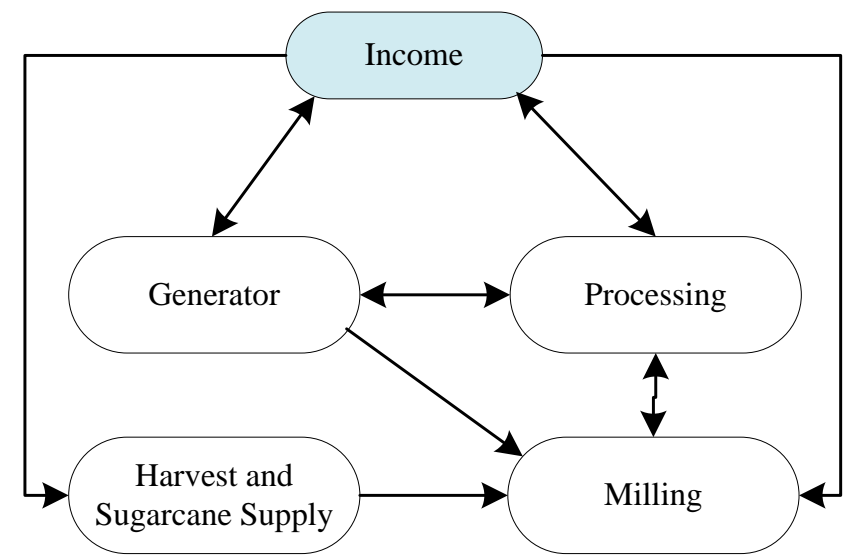

Figure 6:-Model structure of risk treatment simulation

Stock-flow diagram is constructed on the basis of the causal loop diagrams and structural models. The flow chart of the two sub-models of TMA and milling is presented as follows:

\section{SFD of TMA sub-model:-}

TMA sub-model consists of 3 levels or stock namely sugar cane planting area in the farm whose value continues to decrease in line with the sugarcane harvest flow, sugarcane stock in plantation which the amount increased by sugarcane harvest flow and reduced by the transport flow, and sugarcane stock in emplacement whose value increases due to transport flow and reduced by milling flow. It was assumed that all sugar cane that harvested in the day is transported and arrived at the emplacement. This means that the amount of daily transport is equal to the amount of daily sugarcane harvesting. Such an assumption is intended to simplify the model in relation to the data availability, namely the daily data of the amount of sugarcane entering to emplacement and the amount of milled sugar cane. SFD of TMA sub-model is presented in Figure 7. 


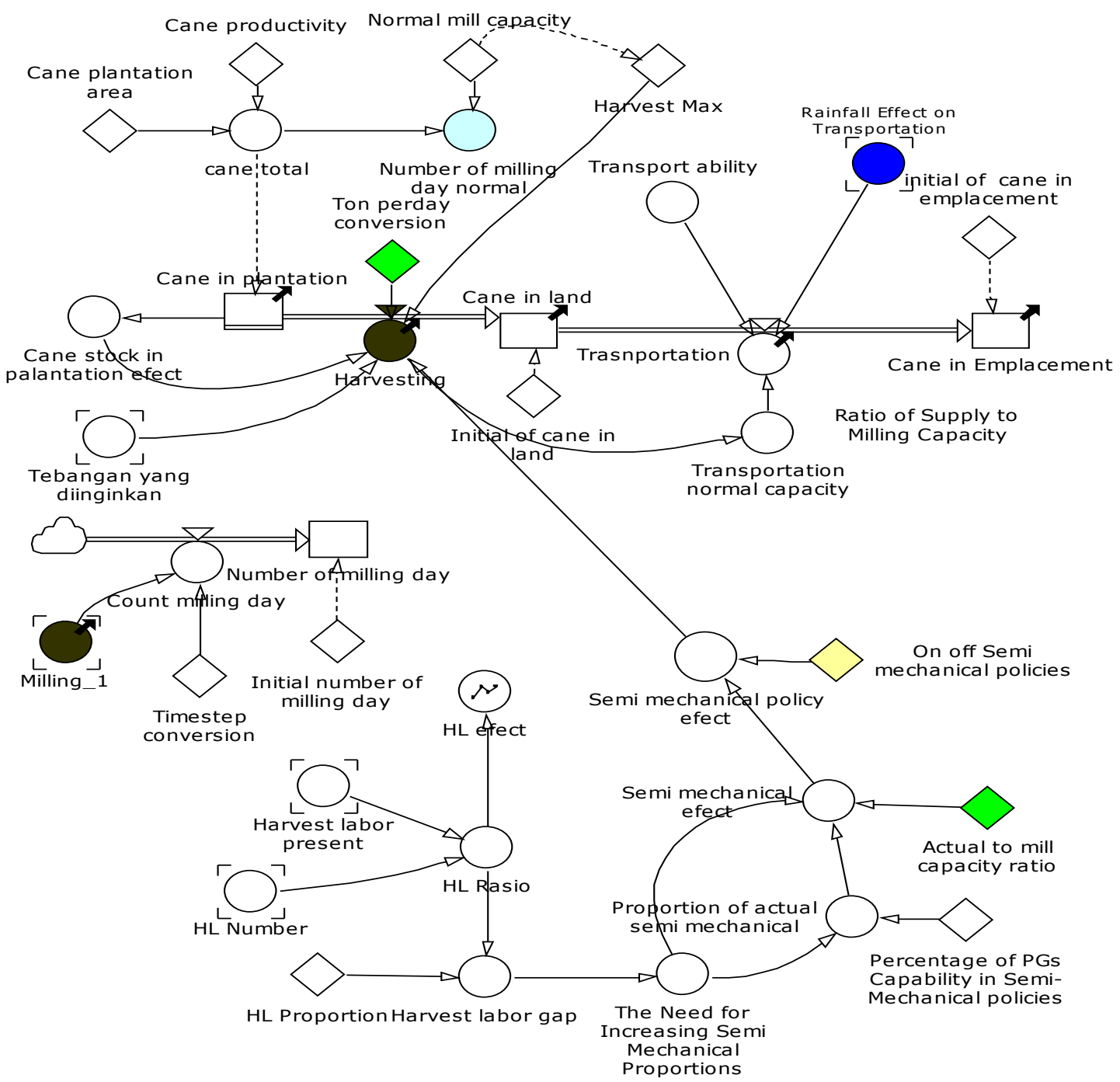

Figure 7:- Flowchart of TMA submodel

\section{Stock Flow Diagram of Milling Sub-model:-}

Milling sub-model was constructed to study the dynamics of milling process during the milling season. There are 2 main stocks in this sub-model: raw sugar cane extract model and bagasse model. Both are the results of the sugarcane milling process which has been added by imbibitions water. Imbibitions' water comes from condensate water in the evaporation process. The raw sugar cane extract will continue to flow for the refining process and the bagasse will be flowed into the storage room and later to the combustion chamber. In this model, it is assumed that the burned bagasse comes from the storage room. If the bagasse from milling station is insufficient to fuel the boiler, an additional supply will be taken from existing bagasse stock. Any excess bagasse will be stored as stock to fuel the boiler engine on the next milling day. Stock-flow diagram of the milling sub-system is presented in Figure 8. 


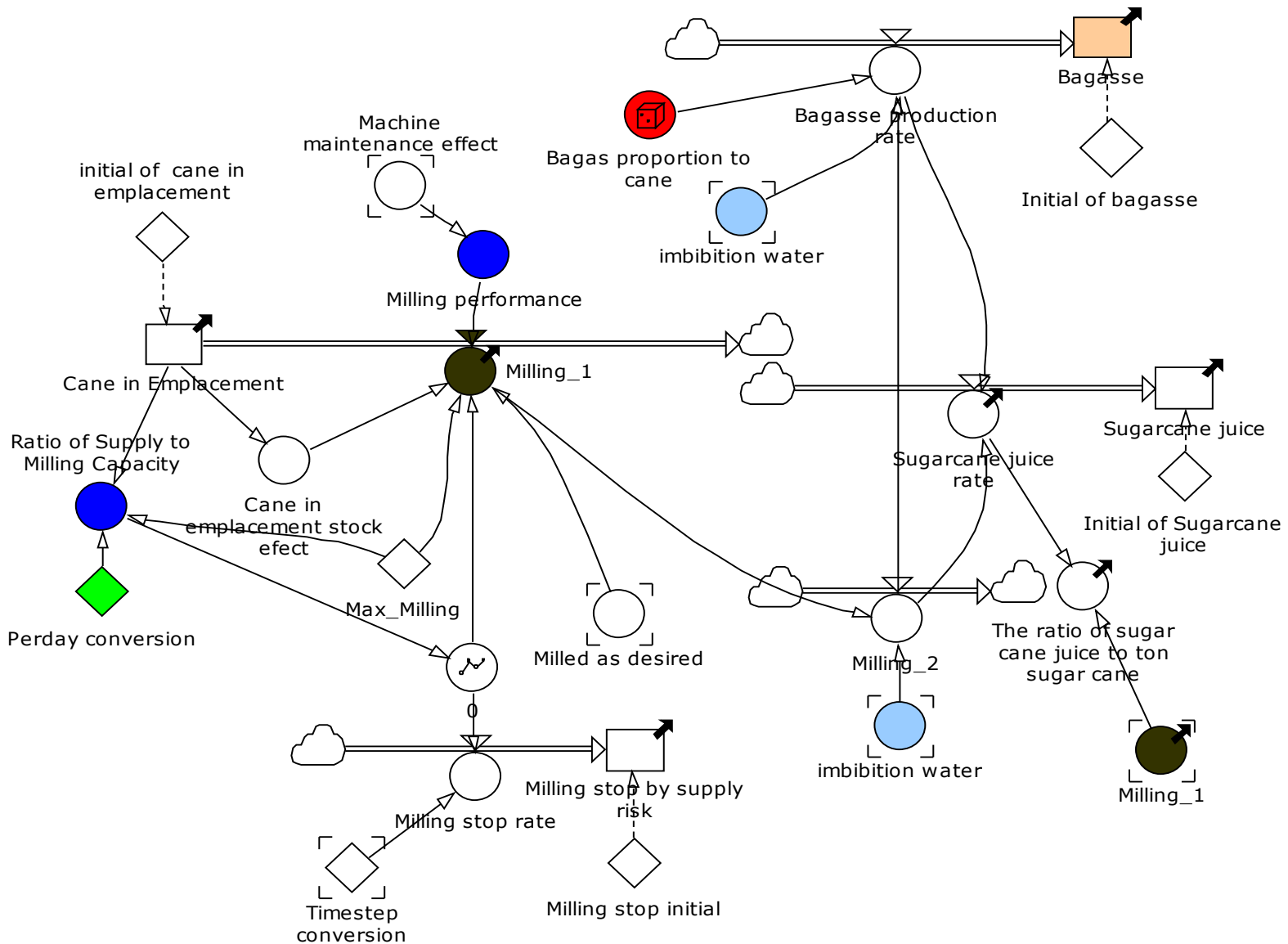

Gambar 8:-Sub-model milling flowchart diagram

\section{Simulation Result:-}

A simulation is performed based on risk treatment scenario for supply risk caused by a lack of harvesting labor and sugar cane cleanliness risks due to less rigorous application o TMA SOP. The measures are the increase of the semimechanical cutting proportion to overcome the shortage of harvesting labor which causes a shortage of average daily supply (14\%) and an increased supervision, reward and punishment for harvest labor for an improved compliance to the SOPs, to increase the level of sugarcane cleanliness near to the standard bellow $5 \%$

A comparison of the performance dynamics between the actual data and the results of scenario simulations is presented in Figure 9, while the percentage of scenario results for the actual data is shown in Figure 10.

Figure 10 shows a change in the average number of sugarcane entering emplacement, daily mill average, and number of cutting days, trash rate, yield, SHS sugar, crystal, molasses, electricity, production costs and income after implementation of risk management scenarios:

1. A decrease of more than $30 \%$ on trash rate after implementation of TMA SOP enforcement scenarios and combined scenarios

2. An increase of more than $10 \%$ on average of sugarcane entering emplacement, daily milling average, and number of milled days after semi-mechanical cutting and combination scenario

3. An increase of more than $5 \%$ on yield, SHS sugar, crystal, income, and production costs for scenarios for SOP enforcement and combined scenarios, whereas due to a semi-mechanical cutting scenario, there is an increase of less than $5 \%$. 


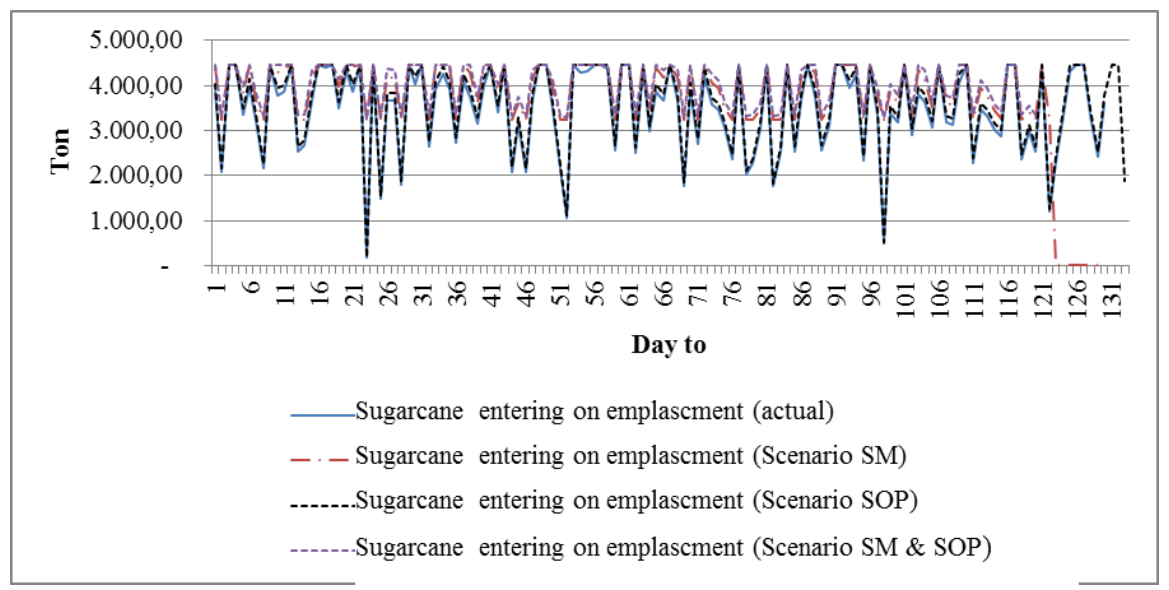

Figure 9:-Dynamics of daily cutting performance between actual conditions, scenario: BC, SOP, and combination

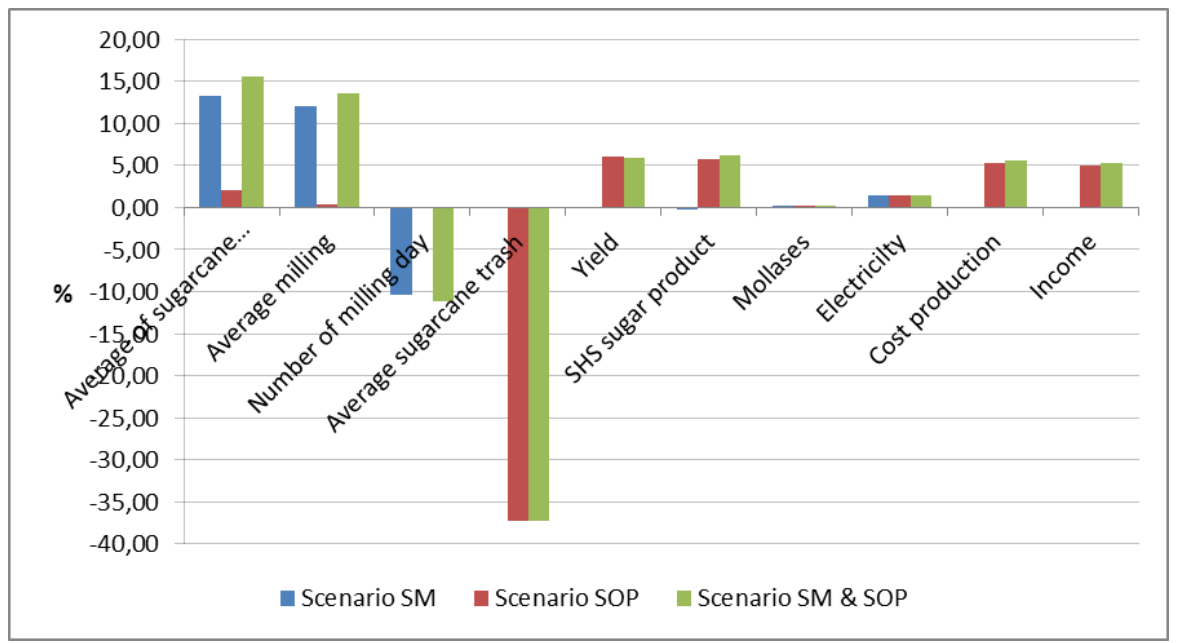

Figure 10:-Changes in simulation results value of SM scenario, SOP and combination of SM and SOP on the actual

\section{Discussion:-}

The results of the ISM analysis show that TMA management becomes a very important solution to overcome risks in TMA activities and post-activities affected by TMA activities risk causing the under performance of the TMA achievement.

In many sugar factories, the source of raw materials comes from farmers. TMA activity is not even fully in the control of PG management. Thus, the risks will be greater. It is known that the sugar loss due to mismanagement in this activity is quite large.

Risks treatment in TMA activities are very important to be performed. It means that the risks in this activity have a significant role in sugar factory performance. This also shows that problems in TMA activities are more complex due the involvement of many actors and external risks beyond the control of PG management. Therefore, managing TMA risk is increasingly important.

This study also shows that even in the cases where the raw material originating from an internal farm, TMA risk is still a high priority. Thus, it is especially important for the cases where the raw material does not come from an external farm. A simulation of risk treatment in TMA provides benefits to the sugarcane volume and quality while at the same time improving the performance of the production process subsystem. 


\section{Conclusion:-}

High impact and low difficulty risk treatment are:

1. Improvement of TMA planning management with rainy days forecast

2. Implementation of TMA SOP, Reward \& Punishment

3. Improvement of communication systems among production line with TMA

4. Improvement of TMA management in supply management

The risk treatment simulation model is able to forecast changes in the performance variable of sugar cane production processes such as yield, SHS sugar, molasses, crystal, electricity, and sugar cane hygiene level.

The improvement of semi-mechanical harvesting combined with the quality enforcement of TMA SOPs implementation produces a better improvement in the performance variable of the sugar production process.

\section{References: -}

1. AGI. (2018). Perkembangan produksi musim giling tahun 2017 Jakarta: AGI Retrieved from http://asosiasigulaindonesia.org/wp-content/uploads/2018/.

2. Bromiley, P., McShane, M., Nair, A., \& Rustambekov, E. (2015). Enterprise Risk Management: Review, Critique, and Research Directions. Long Range Planning, 48(4). doi: 10.1016/j.lrp.2014.07.005

3. Campuzano, F., \& Mula, J. (2011). Supply Chain Simulation A System Dynamics Approach for Improving Performance. London Springer.

4. Dibyoseputro, M. A. B. (2012). Rancang Bangun Sistem Dinamis Pengambilan Keputusan Kompleks Pengembangan Agroindustri Gula Tebu. (Doktor Desertasi), IPB, Bogor.

5. Eriyatno. (2012). Ilmu sistem: meningkatkan mutu dan efektifitas manajemen jilid satu. Surabaya: Guna Widya.

6. Haryono, Hendriadi, A., Sembiring, H., Unadi, A., \& Nurjaman. (2012). Kebijakan Pencapaian Swasembada Dan Swasembada Berkelanjutan Lima Komoditas Utama Pertanian Melalui Pendekatan Sistem Dinamik. Jakarta: BP3 Kementan.

7. Minami, N. A., Madnick, S., \& Rhodes, D. (2008, 12-15 November 2008). A Systems Approach to Risk Management. Paper presented at the American Society For Engineering Management Conference Proceedings.

8. Nasirzadeh, F., Afshar, A., Khanzadi, M., \& Howick, S. (2008). Integrating system dynamics and fuzzy logic modelling for construction risk management. Construction Management and Economics, 26(11), 1197-1212. doi: $10.1080 / 01446190802459924$

9. Nikolaou, I., Evangelinos, K., \& Leal Filho, W. (2014). A system dynamic approach for exploring the effects of climate change risks on firms' economic performance. Journal of Cleaner Production. doi: 10.1016/j.jclepro.2014.09.086

10. Patill, G. V., G.S.Yarnal., \& V.S.Puranik. (2008). System Dynamics Modelling Approach For Energy Management in a Sugar Industry. Journal of Contemporary Research in Management, 3.

11. Rohmatulloh, Marimin, Machfud, \& Nasution, M. Z. (2009). Kajian Sistem Pengukuran Kinerja Pabrik Gula (Studi Kasus, Pg Subang Jawa Barat). Jurna Manajemen \& Agribisnis, 6.

12. Rohmatulloh, Marimin, Machfud, \& Nasution, M. Z. (2011). Pengembangan Model Sistem Dinamik Kinerja Pabrik Gula. Paper presented at the 2nd Workshop on System Modelling for Policy Development : Rehearsing Strategic Initiatives, Jakarta.

13. Sargent, R. G. (2012). Verification and validation of simulation models. Journal of Simulation, 7(1), 12-24. doi: 10.1057/jos.2012.20

14. Sidola, A., Kumar, P., \& Kumar, D. (2011, 27-30 June 2011). System dynamic methodological approach for design and analysis of risk in supply chain. Paper presented at the First International Technology Management Conference.

15. Sriwana, I. K. (2006). Pemodelan Sistem untuk Peningkatan Produksi Gula Tebu PG Rajawali II Unit PG Subang. (Master Thesis), IPB, Bogor.

16. Sterman, J. D. (2000). Business Dynamics: Systems Thinking and Modeling for a Complex World (1 ed.). New York: McGraw-Hill Education.

17. Subiyanto. (2017). Analisis keragaman parameter penentu rendemen gula kristal putih pada pabrik gula bumn. MIPI, $11,1-10$.

18. Suripto, Machfud, Romli, M., \& Rosidi, A. (2018). Risk Analysis and Mitigation Strategy for Sugar Cane Production Processes (Case Study: X Sugar Cane Factory-West Java). Paper presented at the IOP Conference Series: Earth and Environmental Science.

19. Wan, J., \& Liu, Y. (2014). A System Dynamics Model for Risk Analysis during Project Construction Process. Open Journal of Social Sciences, 02(06), 451-454. doi: 10.4236/jss.2014.26052. 